\section{Response to: 'Not all drugs (and routes) are same' by Zanwar and Gandhi}

We would like to thank Zanwar and Gandhi ${ }^{1}$ for their comments regarding our paper. ${ }^{2}$ We are aware of the long-term results of the European Vasculitis Society (EUVAS) trial: patients treated with daily oral (DO) cyclophosphamide experienced fewer relapses than those given pulse intravenous cyclophosphamide for induction therapy. ${ }^{3}$ At 18 months, no significant between-group differences were seen and long-term follow-up indicated fewer relapses only for the DO cyclophosphamide group. However, as mentioned by the authors, the study was retrospective and approximately $10 \%$ of the data were missing, which might have modified their results. The DO versus pulse difference in relapse rates could be explained by those groups' different cumulative (median (IQR) cyclophosphamide doses, respectively: 15.9 (11-22.5)g vs 8.2 $(5.95-10.55) \mathrm{g})$. The excess relapses in the pulse arm were not associated with higher mortality or more renal damage. In light of the well-known increased risk of adverse events when DO cyclophosphamide is prescribed (infertility, malignancies, infections), we no longer recommend it as first-line therapy. Since the demonstration of rituximab non-inferiority to oral cyclophosphamide to induce antineutrophil cytoplasm antibody (ANCA)-associated vasculitis remission, ${ }^{4}$ we have modified our cyclophosphamide use strategy. We prescribe DO cyclophosphamide only for patients with refractory disease, after pulse cyclophosphamide and rituximab have failed. In the MAINRITSAN2 trial, only one patient in the fixed-schedule infusion arm received oral cyclophosphamide for induction versus none in the individually tailored arm.

Based on the post-hoc analysis of the RAVE trial data, Fussner et $a l^{5}$ reported that higher antiproteinase-3 ANCA titres were associated with relapses only in patients who had received rituximab as induction therapy; this group of patients did not receive any maintenance therapy. No ANCA-titre-relapse association was found for patients taking DO cyclophosphamide followed by azathioprine. We do not think that their observed association could affect MAINRITSAN2 results because, after remission was obtained with different induction regimens, all patients received rituximab for maintenance at randomisation, thereby rendering the population homogeneous.

\section{Pierre Charles, ${ }^{1,2}$ Loic Guillevin ${ }^{1}$}

${ }^{1}$ Internal Medicine, Referral Center for Rare Systemic and Autoimmune Diseases: Vasculitis and Scleroderma, Cochin Hospital, Paris Descartes University, Paris, France

${ }^{2}$ Department of Internal Medicine, Institut Mutualiste Montsouris, Paris, France

Correspondence to Professor Loic Guillevin, Department of Internal Medicine, Hôpital Cochin, Paris 75679, France; loic.guillevin@orange.fr

Handling editor Josef $S$ Smolen

Funding The authors have not declared a specific grant for this research from any funding agency in the public, commercial or not-for-profit sectors.

Competing interests None declared.

Patient consent Not required.

Provenance and peer review Commissioned; internally peer reviewed.

(c) Article author(s) (or their employer(s) unless otherwise stated in the text of the article) 2019. All rights reserved. No commercial use is permitted unless otherwise expressly granted.

\section{Check for updates}

To cite Charles P, Guillevin L. Ann Rheum Dis 2019;78:e75.

Received 14 May 2018

Accepted 14 May 2018

Published Online First 1 June 2018

\section{SPlinked}

- http://dx.doi.org/10.1136/annrheumdis-2018-213730

Ann Rheum Dis 2019;78:e75. doi:10.1136/annrheumdis-2018-213742

\section{REFERENCES}

1 Zanwar A, Gandhi S. Not all drugs (and routes) are same. Ann Rheum Dis 2019;78:e74.

2 Charles P, Terrier B, Perrodeau É, et al. French Vasculitis Study Group. Comparison of individually tailored versus fixed-schedule rituximab regimen to maintain ANCAassociated vasculitis remission: results of a multicentre, randomised controlled, phase III trial (MAINRITSAN2). Ann Rheum Dis 2018;77:1143-9.

3 Harper L, Morgan MD, Walsh M, et al. Pulse versus daily oral cyclophosphamide for induction of remission in ANCA-associated vasculitis: long-term follow-up. Ann Rheum Dis 2012;71:955-60.

4 Stone JH, Merkel PA, Spiera R, et al. Rituximab versus cyclophosphamide for ANCAassociated vasculitis. N Engl I Med 2010;363:221-32.

5 Fussner LA, Hummel AM, Schroeder DR, et al. Factors determining the clinical utility of serial measurements of antineutrophil cytoplasmic antibodies targeting proteinase 3 . Arthritis Rheumatol 2016;68:1700-10. 